\title{
Dynamika migracji z Polski do Niemiec i charakterystyka polskiej zbiorowości ${ }^{1}$
}

\begin{abstract}
Dynamics of migration from Poland to Germany and characteristics of the Polish community: The article provides an overview of the dynamics of migration from Poland to Germany and the socio-demographic characteristics of Polish community. It begins with the history of migration processes between the two countries, with special focus on the most important periods (including post-accession migration). Next, the socio-demographic characteristics of the Polish community are analyzed, including its size, distribution, education and labour market situation. A comparison between the Polish community and the entire migrant community in Germany is conducted as well.
\end{abstract}

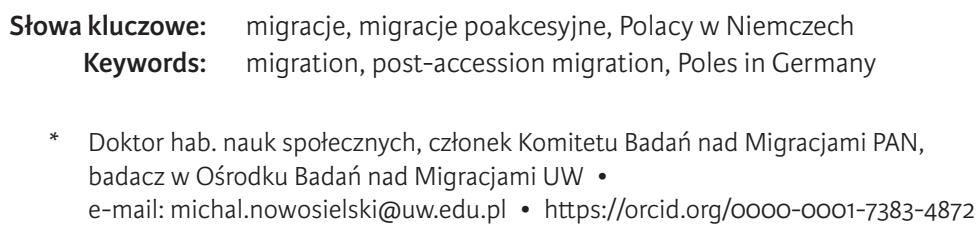

\section{Wstęp}

Choć migranci z Polski w Niemczech stanowią dużą i ważną zbiorowość zarówno z perspektywy Polski, jako kraju pochodzenia, jak i Niemiec, jako kraju pobytu - to jednak z jakichś powodów nie przyciągają oni zbytniej uwagi badaczy ani po jednej, ani po drugiej stronie Odry. Słabo są także obecni w międzynarodowej naukowej debacie wokół migracji - nasza wiedza na ich temat w porównaniu np. z Polakami mieszkającymi w Wielkiej Brytanii czy

${ }^{1} \mathrm{~W}$ artykule wykorzystano dane zebrane podczas realizacji projektu badawczego „Polskie organizacje imigranckie w Europie” prowadzonego w Ośrodku Badań nad Migracjami Uniwersytetu Warszawskiego w latach 2017-2020 (wcześniej prowadzonego w Instytucie Zachodnim w latach 2015-2016). Projekt jest realizowany ze środków Narodowego Centrum Nauki z siedzibą w Krakowie w ramach konkursu SONATA BIS (nr 2014/14/E/HS6/00731). 
Stanach Zjednoczonych jest raczej niewielka i fragmentaryczna ${ }^{2}$. Co więcej, Polacy w Niemczech w niewielkim stopniu przyciągają uwagę praktyków społecznych i politycznych - uważani za dobrze integrujących się w społeczeństwie niemieckim rzadko pojawiają się w ważnym niemieckim dyskursie integracyjnym $^{3}$, z kolei z perspektywy polityki polonijnej są, co prawda, grupą istotną, ale traktowaną w sposób raczej schematyczny, bez głębszej refleksji na temat jej współczesnej sytuacji. Zbiorowość w związku z tym opisywana bywa jako niewidoczna bądź wręcz niewidzialna ${ }^{4}$.

Tymczasem, biorąc pod uwagę z jednej strony wielkość tej zbiorowości, z drugiej zaś jej dynamiczne przemiany w ostatnich latach, powinniśmy baczniej się jej przyglądać. Celem artykułu jest dokonanie przeglądu naszej wiedzy na temat Polaków w Niemczech - przede wszystkim z perspektywy dynamiki migracji z Polski do Niemiec oraz charakterystyki społeczno-demograficznej tej zbiorowości, także w ujęciu porównawczym. W pierwszym rzędzie dokonana zostanie analiza dotycząca historii procesów migracyjnych między oboma krajami - omówione będą najważniejsze okresy, które charakteryzowały się różną dynamiką: okres rewolucji przemysłowej i Cesarstwa Niemieckiego do wybuchu I wojny światowej, okres międzywojenny, czas II wojny światowej, okres zimnej wojny oraz migracje przed- i poakcesyjne. Ponadto przeanalizowana zostanie charakterystyka społeczno-demograficzna współczesnej zbiorowości migrantów z Polski w Niemczech. Opisane będą najważniejsze cechy tej zbiorowości oraz - w wybranych aspektach - przeprowadzone porównanie między tą grupą a całą zbiorowością imigrancką w RFN oraz zbiorowością Niemców bez pochodzenia migracyjnego.

\section{Historia polskich migracji do Niemiec}

\section{Początki}

Polskie migracje do Niemiec trwają niemal nieprzerwanie od dwustu lat. Pierwsze fale wychodźstwa polskiego do Niemiec pojawiły się na początku XIX wie-

2 M. Nowosielski, Polacy w Niemczech. Stan i perspektywy badań, „Przegląd Zachodni” 2012, nr 3 .

3 Zob. np. badanie Infratest dla „Welt am Sonntag”, http://www.infratest-dimap.de/ umfragen-analysen/bundesweit/umfragen/aktuell/gutes-verhaeltnis-zwischen-deutschen-und-polen/ [dostęp: 16 kwietnia 2012 r.]; P. Cichocki, A. Lewandowska, M. Nowosielski, Dynamika niemieckiej opinii publicznej. Wizerunek Polski i Polaków w Niemczech, „IZ Policy Papers" 2013, nr 8.

${ }^{4}$ O. Schmidtke, Die „unsichtbare” polnische Community in Deutschland: Die strategische Entdramatisierung von kollektiver Identität [w:] Die Einhegung des Anderen. Türkische, polnische und russlanddeutsche Einwanderer in Deutschland, eds. K. Eder, V. Rauer, O. Schmidtke, VS Verlag, 2004; P. Loew, Wir Unsichtbaren. Geschichte der Polen in Deutschland, CH Beck, München 2014. 
ku. Rozbiory Polski oraz seria nieudanych powstań $(1794,1831,1848,1863)$ spowodowały, że wielu Polaków zdecydowało się opuścić Polskę lub zostało zmuszonych do migracji ${ }^{5}$.

Rozbiory spowodowały również, że Polacy zamieszkujący tereny zaboru pruskiego stali się mimowolnie polską mniejszością w Prusach. Z około $8 \mathrm{mln}$ mieszkańców Królestwa Pruskiego 3 mln stanowili Polacy ${ }^{6}$. W wyniku wojen napoleońskich i ustaleń Kongresu Wiedeńskiego populacja Polaków w Prusach zmniejszyła się do 1,5 $\mathrm{mln}^{7}$. W $1871 \mathrm{r}$. ludność polska, skupiona głównie w pro-

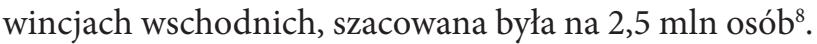

Choć migracje zarobkowe Polaków do Niemiec rozpoczęły się już w pierwszej połowie XIX wieku' ${ }^{9}$, to dopiero zjednoczenie Niemiec i stworzenie Cesarstwa Niemieckiego w 1871 r., które rozpoczęło proces gwałtownego rozwoju przemysłowego i ekonomicznego państwa, spowodowało zwiększone zapotrzebowanie na siłę roboczą zarówno w przemyśle, jak i w rolnictwie ${ }^{10}$. Polacy stanowili jedno z głównych źródeł siły roboczej koniecznej do zaspokojenia tego zwiększonego popytu. Początkowo migracje Polaków były przede wszystkim migracjami wewnętrznymi - Polacy mieszkający na terenie zaboru pruskiego przenosili się w głąb Cesarstwa Niemieckiego do ośrodków rozwijającego się przemysłu. Z czasem coraz bardziej zwiększające się zapotrzebowanie na siłę roboczą sprawiło, że na tereny Cesarstwa Niemieckiego zaczęła napływać ludność polska także z terenów zaborów rosyjskiego i austriackiego ${ }^{11}$. Należy jednak zauważyć, że w dużej części przypadków Polacy pochodzący ze wschodu osiedlali się głównie na terenie Prus i swoją pracą zasilali niemieckie rolnictwo.

Szacuje się, że w latach 1870-1914 do Niemiec wyemigrowało 3,5 mln Polaków. Około 1,2 mln osób przemieściło się z terenów zaboru pruskiego w głąb Cesarstwa Niemieckiego, kolejne 1,2 mln Polaków wyemigrowało z terenów zaboru rosyjskiego, zaś mniej niż 1,1 mln polskich imigrantów w Niemczech pochodziło

${ }^{5}$ G. Janusz, Polonia w Niemczech [w:] Polonia w Niemczech. Historia i współczesność, Elipsa, Warszawa 2001, s. 21.

${ }^{6}$ P. Panayi, Ethnic Minorities in Nineteenth and Twentieth Century Germany. Jews, Gypsies, Poles, Turks and Others, Longman, Harlow 2000, s. 54.

7 Ibidem.

${ }^{8}$ W. Lesiuk, Polska emigracja wewnątrzniemiecka i do Niemiec okresu industrializacji [w:] Polacy w Niemczech, red. M. Lis, Instytut Śląski, Opole 1996, s. 11.

9 Zob. A. Pilch, Emigracja z ziem zaboru austriackiego (od połowy XIX w. do 1918 r.) [w:] Emigracja z ziem polskich w czasach nowożytnych i najnowszych (XVIII-XX w.), red. A Pilch, PWN, Warszawa 1984.

10 W. Lesiuk, Polska emigracja, op. cit., s. 11.

11 A. Plich, Ogólne prawidłowości emigracji z ziem polskich. Próba typologii i syntezy [w:] Stan i potrzeby badań nad zbiorowościami polonijnymi, red. H. Kubiak, A. Pilch, Zakład Narodowy imienia Ossolińskich, Wrocław 1976, s. 35-49. 
z terenów zaboru austriackiego ${ }^{12}$. Najbardziej popularnymi miejscami osiedlania się polskich imigrantów była Nadrenia Północna-Westfalia, na terenie której na przełomie XIX i XX wieku mieszkało od $300^{13}$ do 500 tys. ${ }^{14}$ Polaków. Ponadto ludność Polska osiedlała się w innych ośrodkach przemysłowych, np. na terenie Saksonii (m.in. w Dreźnie, Magdeburgu, Mansfeldzkim Okręgu Miedziowym około 45-90 tys. osób ${ }^{15}$ ), w prowincji hanowerskiej czy Hamburgu. Dynamicznie rozwijająca się stolica Cesarstwa Berlin również przyciągała licznych Polaków, których liczba na przełomie XIX i XX wieku przekroczyła 100 tys. osób ${ }^{16}$.

\section{Okres międzywojenny}

Pierwsza wojna światowa oraz utworzenie niepodległego państwa polskiego w 1918 r. zmieniły sytuację. Powstanie Rzeczypospolitej Polskiej spowodowało, że część ziem byłego Cesarstwa Niemieckiego zamieszkałych przez Polaków została przyłączona do Polski. Zmniejszyło to znacznie populację Polaków mieszkających na terenach Republiki Weimarskiej, choć nadal pozostała ona znaczna i wynosiła około 1,5 mln osób ${ }^{17}$. Największymi skupiskami były: Górny Śląsk (600-800 tys.), Prusy Wschodnie (400-550 tys.), Niemcy Środkowe (120-150 tys.), Niemcy Zachodnie (95-120 tys.) ${ }^{18}$.

Jednak nie tylko przesunięcie granic zmieniło liczbę Polaków w Niemczech. Ważnym czynnikiem kształtującym liczebność polskiej społeczności w Niemczech były także migracje powrotne ${ }^{19}$ oraz dalsze migracje do innych krajów przemysłowych - przede wszystkim do Francji i Belgii ${ }^{20}$. Krystian Heffner szacuje, że z samej Westfalii wyemigrowało około 250 tys. Polaków, z czego po 100 tys. osób do Polski i Francji i 50 tys. do innych krajów (Belgii, USA, Kanady, Argentyny)21.

12 A. Galos, Stan liczebny emigracji polskich $w$ XIX wieku [w:] Liczba i rozmieszczenie Polaków w świecie, cz. 1, Uniwersytet Wrocławski, Wrocław 1981, s. 31-35; zob. A. Plich, Ogólne prawidłowości emigracji, op. cit., s. 35-49.

13 G. Janusz, Polonia w Niemczech, op. cit., s. 21.

14 W. Lesiuk, Polska emigracja, op. cit., s. 15-16.

15 Ibidem.

16 A. Cimała, Polacy w Berlinie w XIX i XX wieku [w:] Polacy w Niemczech, red. M. Lis, Instytut Śląski, Opole 1996, s. 30.

${ }_{17}$ M. Lis, Polska mniejszość narodowa w Niemczech po odzyskaniu niepodległości przez Polskę [w:] Polacy w Niemczech, red. M. Lis, Instytut Śląski, Opole 1996, s. 19.

18 Ibidem.

19 Warto jednak zwrócić uwagę, że część z tych migracji powrotnych była tylko chwilowa, bowiem pewna liczba migrantów po pewnym czasie zdecydowała się na powrót do Niemiec, zob. P. Panayi, Ethnic Minorities, op. cit., s. 150.

${ }^{20}$ J. Kozłowski, Geneza i ewolucja zbiorowości wychodźstwa polskiego w Europie [w:] Polonia w Europie, red. B. Szydłowska-Cegłowa, Zakład Badań Narodowościowych PAN, Poznań 1992.

${ }^{21}$ K. Heffner, Polacy w Niemczech - rozmieszczenie i liczebność [w:] Polacy w Niemczech, red. M. Lis, Instytut Śląski, Opole 1996, s. 49. 
W okresie międzywojennym polska migracja do Niemiec zmieniła swój charakter. Migracje stałe zostały zahamowane, a migracje sezonowe uległy ograniczeniom ${ }^{22}$.

\section{Il wojna światowa i jej konsekwencje}

Podczas II wojny światowej w wyniku prowadzonej przez III Rzeszę polityki zwiększania zasobów siły roboczej z terenów włączonych do Rzeszy oraz okupowanych przymusem przesiedlono na terytorium III Rzeszy od około $1,9^{23}$ do 2,5 mln Polaków ${ }^{24}$. Byli to przede wszystkim robotnicy przymusowi, więźniowie obozów koncentracyjnych oraz stalagów i oflagów. Polacy stanowili w Niemczech najliczniejszą, stanowiącą nawet do $60 \%$ ogółu, grupę cudzoziemskich robotników ${ }^{25}$. Nie należy także zapominać o wywozie około 200 tys. polskich dzieci w celu germanizacji ${ }^{26}$. Bezpośrednio po zakończeniu działań wojennych Polacy, którzy zostali przymusowo przesiedleni na terytorium III Rzeszy, znaleźli się w różnych strefach okupacyjnych (700 tys. w radzieckiej, 540 tys. w brytyjskiej, 400 tys. w amerykańskiej i 68 tys. we francuskiej) ${ }^{27}$. Większość z nich otrzymała status wysiedlonych - displaced persons (potocznie nazywanych dipisami). W wyniku akcji repatriacyjnej duża część dipisów wróciła do ojczyzny, część zaś podjęła - przede wszystkim z przyczyn politycznych - decyzję o dalszej migracji do innych państw Europy Zachodniej. Akcja repatriacyjna najsprawniej została przeprowadzona w radzieckiej strefie okupacyjnej - do końca 1946 r. niemal wszyscy wysiedleni z tej strefy wrócili do Polski ${ }^{28}$. Pewna liczba dipisów zdecydowała się zostać na terenie Niemiec Zachodnich ${ }^{29}$. Szacuje się, że w 1950 r. na terytorium RFN znajdowało się około 80 tys. dipisów ${ }^{30}$, którzy

22 E. Marek, Praca Polaków w Niemczech, op. cit., s. 90.

${ }^{23}$ Ibidem, s. 191.

${ }^{24}$ Z. Landau, Polityka ludnościowa Niemiec hitlerowskich za ziemiach polskich w latach II wojny światowej, „Wiadomości Historyczne. Czasopismo dla Nauczycieli” 1964, t. 7, nr 4, s. 161-170, za: J. Korczyńska, Sezonowe wyjazdy Polaków do Niemiec, Scholar, Warszawa 2003, s. 45.

25 M. Krajewski, Historia gospodarcza Polski do 1989 roku, Wyższa Szkoła Humanistyczno-Ekonomiczna, Włocławek 2000, s. 383.

26 C. Łuczak, Przemieszczenia ludności z Polski podczas drugiej wojny światowej [w:] Emigracja z ziem polskich w czasach nowożytnych i najnowszych (XVIII-XX w.), red. A Pilch, PWN, Warszawa 1984, s. 455-480.

27 E. Marek, Praca Polaków w Niemczech, op. cit., s. 192.

28 G. Janusz, Polonia $w$ Niemczech, op. cit., s. 27.

29 Była to zbiorowość dość dobrze zorganizowana, zob. np. Ł. Wolak, Środowisko Zjednoczenia Polskich Uchodźców w RFN. Przyczynek do badań [w:] Z dziejów polskiej emigracji politycznej po 1939 r. Ludzie, struktury, idee, red. P. Pleskot, IPN, Warszawa 2019.

${ }^{30}$ K. Ruchniewicz, Die polnische politische Emigration nach Deutschland in den Jahren 1945 bis 1980 [w:] Die Migration von Polen nach Deutschland. Zu Geschichte und Gegenwart eines europäischen Migrationssystems, ed. Ch. Pallaske, Nomos Verlagsgesellschaft, BadenBaden 2001, s. 66. 
uzyskali status bezpaństwowców (heimatlose Ausländer) ${ }^{31}$. Liczebność tej grupy zmalała jeszcze w połowie lat 50 . XX wieku do około 50 tys. ${ }^{32}$.

W wyniku II wojny światowej zmieniła się także liczba i położenie przedwojennej polskiej mniejszości mieszkającej w Niemczech. Przede wszystkim wpłynęła na to zmiana granic, która spowodowała, że polska ludność autochtoniczna mieszkająca na terenie Dolnego Śląska, Prus Wschodnich czy Pomorza znalazła się na terytorium Polski. W granicach powojennych Niemiec znaleźli się jedynie Polacy mieszkający w Niemczech Środkowych i Zachodnich. Ich liczba szacowana jest na od około 100 do 200 tys. osób ${ }^{33}$. Większość z nic mieszkała w Zagłębiu Ruhry (ok. 100 tys.), na terenie Berlina (ok. 20 tys.), Hamburga (10 tys.), Hanoweru, Drezna i Lipska ${ }^{34}$. Położenie przedwojennej mniejszości dodatkowo zmieniło się z powodu polityki władz okupacyjnych. Nie uznawały one zbiorowości polskiej za mniejszość narodową, ale za „Niemców polskiego pochodzenia" ${ }^{35}$.

\section{Czasy PRL}

Choć ze względu na zamknięcie granic PRL migracje były bardzo utrudnione, nie oznacza to, że zupełnie zamarł ruch ludnościowy między Polską a Niemcami. Przede wszystkim do RFN zaczęli napływać z Polski przesiedleńcy (Aussiedler), a następnie tzw. późni przesiedleńcy (Spätaussiedler) ${ }^{36}$. Migracje te rozpoczęły się w latach 50 . XX wieku wyjazdami realizowanymi w ramach tzw. akcji łączenia rodzin, które były prowadzone na mocy porozumienia między Polskim i Niemieckim Czerwonym Krzyżem. Wielkość tej fali migracji jest oceniana na około 250 tys. osób ${ }^{37}$. Dzięki podpisanemu w 1970 r. traktatowi polsko-niemieckiemu w latach 70. wyemigrowało kolejnych 130 tys. osób ${ }^{38}$. Największa fala przesiedleńców przypadła w latach 80 ., kiedy to, powołując się na niemieckie pochodzenie, wyemigrowało z Polski do Niemiec ponad 800 tys. osób. W latach 90. wielkość migracji aussiedlerów znacznie zmalała.

${ }^{31}$ J. Kozłowski, Geneza i ewolucja zbiorowości, op. cit., s. 26; G. Janusz, Polonia w Niemczech, op. cit., s. 28.

32 G. Janusz, Polonia w Republice Federalnej Niemiec, UMCS, Lublin 1990, s. 158-160.

33 K. Heffner, Polacy w Niemczech, op. cit., s. 50.

${ }^{34}$ G. Janusz, Polonia w Niemczech, op. cit., s 27.

35 S. Liman, Polacy $w$ Niemczech po II wojnie światowej [w:] Polonia w Europie, red. B. Szydłowska-Cegłowa, Zakład Badań Narodowościowych PAN, Poznań 1992, s. 245.

${ }^{36}$ Więcej o specyfice migracji przesiedleńców w porównaniu z innymi przykładami repatriacji zob. M. Nowosielski, R. Stefańska, Repatriacja [w:] 25 wykładów o migracjach, red. M. Lesińska, M. Okólski, Scholar, Warszawa 2018.

37 A. Trzcielińska-Polus, „Wysiedleńcy” $z$ Polski $w$ Republice Federalnej Niemiec $w$ latach 1980-1990, Instytut Śląski, Opole, 1997, s. 25.

${ }^{38}$ Ibidem. 
Warta odnotowania jest także wielkość tej fali imigrantów. Szacuje się, że w sumie w latach 1950-1999 z Polski do Niemiec wyemigrowało około $1,2^{39}-1,5^{40} \mathrm{mln}$ przesiedleńców, co, jak zauważa Jacek Schmidt, stanowiło ponad 60\% wszystkich osób wyjeżdżajacych na stałe do Niemiec ${ }^{41}$. Polska do lat 90 . XX wieku była „przodującym" krajem wysyłającym tego typu migrantów ${ }^{42}$. W znacznej części przypadków była to ludność autochtoniczna zamieszkująca polskie ziemie zachodnie i północne ${ }^{43}$ - szczególnie ówczesne województwa opolskie, katowickie i olsztyńskie.

Powodem, dla którego warto zwrócić uwagę na fenomen aussiedlerów, jest fakt, że mimo preferencyjnych zasad ich imigracji i osiedlania się na terenie RFN ich integracja ze społeczeństwem niemieckim nie była pełna. Część z przesiedleńców - szczególnie z lat 80. - nie tylko zachowała bardzo bliskie związki z polskością oraz polską kulturą i językiem, ale także nadal ma polskie obywatelstwo ${ }^{44}$.

Lata 80. to nie tylko czas masowego exodusu osób powołujących się na niemieckie pochodzenie, ale także czas tzw. emigracji solidarnościowej ${ }^{45}$. Była to migracja o podłożu politycznym, składająca się z dysydentów, którzy byli zmuszani do wyjazdu z Polski lub sami podejmowali decyzję o emigracji ${ }^{46}$. Fali tej towarzyszyli także typowi migranci ekonomiczni, którzy opuszczali pogrążony w kryzysie gospodarczym PRL, by w RFN znaleźć lepsze warunki materialne. Część polskich wychodźców z lat 80. łączyła oba te powody ${ }^{47}$. Szacunki dotyczące wielkości tej fali migracyjnej wahają się od $100-150$ tys. ${ }^{48}$ przez 630 tys. ${ }^{49}$ do nawet 850 tys. ${ }^{50}$ osób.

${ }^{39}$ W. Grabe, Górnośląscy „przesiedleńcy” w Niemczech [w:] Być Polakiem w Niemczech, red. A Wolff-Powęska, E. Schulz, Instytut Zachodni, Poznań 2000, s. 236.

${ }^{40} \mathrm{~J}$. Schmidt, Nowe tożsamości w czasach transformacji europejskich. Imigranci $z$ Polski w Niemczech, Wydawnictwo News - Witold Nowak, Poznań 2009, s. 70.

${ }^{41}$ Ibidem.

42 Ibidem.

43 A. Trzcielińska-Polus, Imigracja z Polski do Niemiec w okresie stanu wojennego i po zmianie ustroju w Polsce [w:] Polacy w Niemczech, red. M. Lis, Instytut Śląski, Opole 1996, s. 36.

${ }_{44}$ W. Lesiuk, A. Trzcielińska-Polus, Wokół definicji przedmiotu badań [w:] Być Polakiem w Niemczech, red. A. Wolff-Powęska, E. Schulz, Instytut Zachodni, Poznań 2000, s. 143-144.

45 Zob. np. W. Wrzesiński, Państwo narodowe i świadomość narodowa [w:] Być Polakiem w Niemczech, red. A. Wolff-Powęska, E. Schulz, Instytut Zachodni, Poznań 2000, s. 59.

${ }^{46}$ Należy podkreślić, iż także wcześniejsze przesilenia polityczne w Polsce w latach 1956, 1968, 1970 i 1976 wywoływały fale migracji do Niemiec. Jednak ich wielkość była znacznie mniejsza od emigracji z lat 80., zob. K. Heffner, Polacy w Niemczech, op. cit., s. 46.

47 J. Korczyńska, Sezonowe wyjazdy Polaków, op. cit., s. 48.

48 Ch. Pallaske, Die Migration aus Polen in die Bundesrepublik Deutschland in den 1980er und 1990er Jahren [w:] Die Migration von Polen nach Deutschland. Zu Geschichte und Gegenwart eines europäischen Migrationssystems, ed. Ch. Pallaske, Nomos Verlagsgesellschaft, Baden-Baden 2001, s. 124.

49 K. Slany, Emigracja $z$ Polski w latach osiemdziesiątych do głównych krajów imigracji zamorskiej i kontynentalnej: aspekty demograficzno-społeczne, „Przegląd Polonijny” 1991, t. 62, nr 4, s. 33-35.

50 S. Liman, Polacy w Niemczech, op. cit., s. 251. 


\section{Migracje po 1989 r.}

Upadek komunizmu zahamował nieco dynamikę migracji Polaków do Niemiec. Choć Niemcy nadal pozostały dla Polaków atrakcyjnym celem migracji, to jednak napływ polskich migrantów znacznie się zmniejszył. O ile w $1990 \mathrm{r}$. niemieckie statystyki wykazywały, że na terenie Niemiec mieszka około 240 tys. polskich obywateli, o tyle już pod koniec lat 90. liczba ta wzrosła do ok. 300 tys. Dynamika polskich migracji zwiększyła się na początku XXI wieku - szczególnie rok 2003 był momentem, kiedy odnotowano znaczny napływ Polaków około 45 tys. osób.

W analizach migracji z Polski do Niemiec po 1989 r. niezwykle istotnym zjawiskiem są migracje sezonowe ${ }^{51}$. Już w 1990 r. podpisane zostało oświadczenie ministrów pracy obu państw sankcjonujące sezonową pracę Polaków w Niemczech. Na jej podstawie zalegalizowano rekrutację polskich pracowników sezonowych do pracy w RFN ${ }^{52}$. Główną branżą gospodarki, w której pracowali polscy migranci sezonowi, było rolnictwo, ponadto Polacy byli zatrudniani $\mathrm{w}$ hotelarstwie i gastronomii. Zatrudnienie w innych branżach, takich jak np. budownictwo, było ograniczone, przede wszystkim z powodu protestów niemieckich związków zawodowych ${ }^{53}$. Polscy migranci sezonowi pracowali głównie w starych landach, przede wszystkim w Badenii-Wirtenbergii, Nadrenii Północnej-Westfalii, Dolnej Saksonii, Bremie, Nadrenii-Palatynacie, w mniejszej liczbie w Bawarii. Z nowych landów najwięcej Polaków pracowało sezonowo w Meklemburgii-Pomorzu Przednim ${ }^{54}$. Poza tym możliwe były także inne formy legalnego zatrudnienia Polaków w Niemczech: praca kontraktowa dla zatrudnionych w polskich przedsiębiorstwach, które świadczyły usługi na terenie RFN, status tzw. pracowników-gości (Gastarbeitnehmer), którzy mieli w Niemczech doskonalić swoje umiejętności, pracownicy przygraniczni oraz praca dla studentów. Jak jednak zauważa Ewa Kępińska: okazało się, że zatrudnienie sezonowe odgrywa najważniejszą rolę spośród form legalnego zatrudnienia

${ }^{51}$ Więcej na ten temat zob. np. M. Wagner, K. Fiałkowska, M. Piechowska, W. Łukowski, Niemiecki proszek do prania i polnische Wirtschaft. Polscy robotnicy sezonowi w Niemczech obserwacje etnograficzne, Scholar, Warszawa 2016, lub K. Fiałkowska, Remote fatherhood and visiting husbands: seasonal migration and men's position within familie, „Comparative Migration Studies" 2019, nr 2.

52 Oświadczenie Ministra Pracy i Polityki Społecznej Rzeczpospolitej Polskiej i Ministra Pracy i Polityki Socjalnej Republiki Federalnej Niemiec podpisane 8 grudnia 1990 r., za: E. Kępińska, Migracje sezonowe z Polski do Niemiec, Wydawnictwa Uniwersytetu Warszawskiego, Warszawa 2008, s. 135, pełen tekst oświadczenia ibidem, s. 279-280. Pewnym fenomenem zalegalizowanej migracji sezonowej Polaków do RFN jest to, że objęła ona przede wszystkim osoby już w czasach PRL migrujące do Niemiec i pracujące tam nielegalnie, ibidem, s. 140.

${ }_{53}$ Ibidem, s. 137, zob. także J. Korczyńska, Sezonowe wyjazdy Polaków, op. cit., s. 104.

${ }^{54}$ J. Korczyńska, Sezonowe wyjazdy Polaków, op. cit., s. 108. 


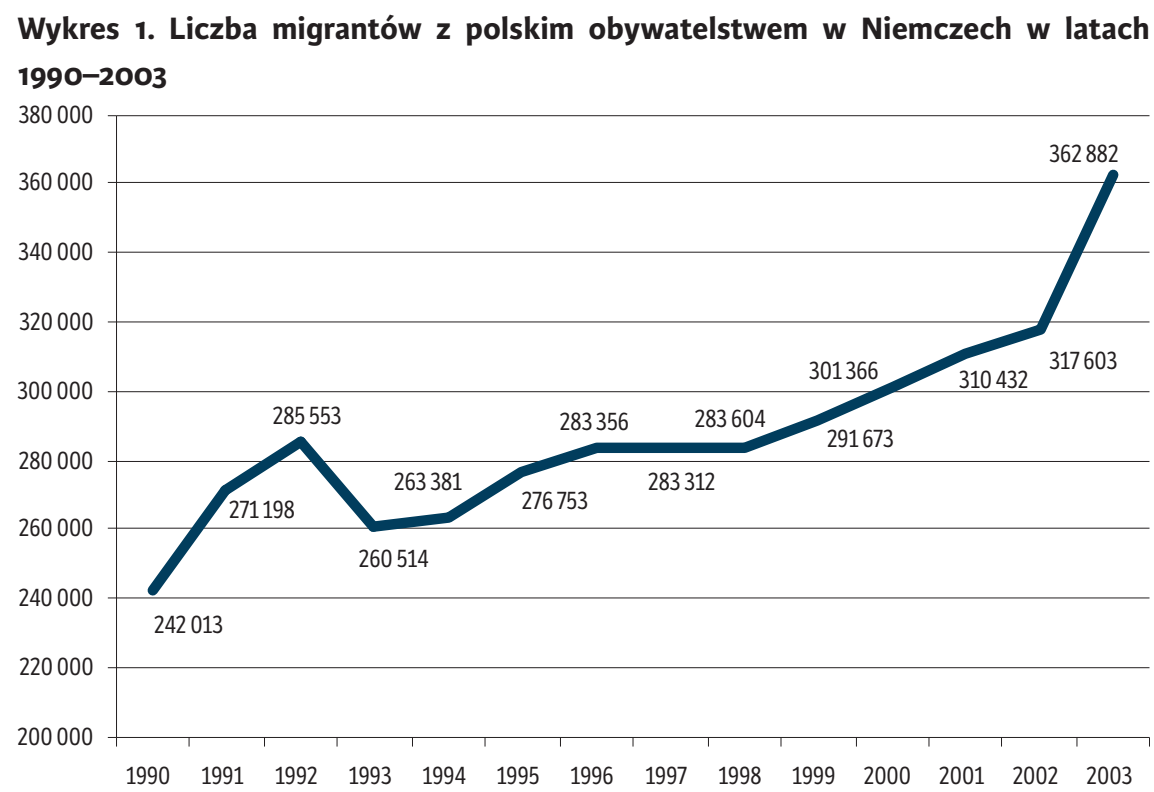

Źródło: Destatis, Bevölkerung und Erwerbstätigkeit Ausländische Bevölkerung sowie Einbürgerungen 2003, Statistisches Bundesamt, Wiesbaden 2005, https://www.destatis.de/GPStatistik/servlets/MCRFileNodeServlet/ DEHeft_derivate_o0003911/2010200037004.pdf; Destatis, Ausländische Bevölkerung nach ausgewählten Staatsangehörigkeiten, https://www.destatis.de/DE/Themen/Gesellschaft-Umwelt/Bevoelkerung/Migration-Integration/Tabellen/auslaendische-bevoelkerung-staatsangehoerigkeit-jahre.html.

$w$ Niemczech ${ }^{55}$. Liczba sezonowych imigrantów z Polski do RFN systematycznie rosła aż do wejścia Polski do UE. W latach 1991-2003 dokonał się ponadczterokrotny wzrost liczby polskich pracowników sezonowych wyjeżdżających do Niemiec. Po tym czasie ich liczba zaczęła spadać.

Obok migracji sezonowych należy wymienić także inne formy migracji tymczasowych z Polski do Niemiec, które doprowadziły do wytworzenia intersującego typu „transmigranta” żyjącego jednocześnie w dwóch (lub więcej) społeczeństwach i kulturach ${ }^{56}$. Ważnym zjawiskiem specyficznym dla migracji między Polską a Niemcami były migracje wahadłowe osób z podwójnym obywatelstwem. Osoby takie, mieszkając na stałe w Polsce, czasowo pracowały na terenie Niemiec, a dzięki niemieckiemu obywatelstwu nie podlegały żadnym re-

55 E. Kępińska, Migracje sezonowe, op. cit., s. 139.

56 F. Miera, Transnationalisierung sozialer Raeume? Migration aus Polen nach Berlin in den 80er und 90er Jahren [w:] Die Migration von Polen nach Deutschland. Zu Geschichte und Gegenwart eines europäischen Migrationssystems, ed. Ch. Pallaske, Nomos Verlagsgesellschaft, Baden-Baden 2001. 
strykcjom na rynku pracy ${ }^{57}$. Nie bez znaczenia były również wahadłowe migracje nielegalne pracowników oraz napływ pracowników kontraktowych ${ }^{58}$. Charakterystyczne szczególnie dla lat 90 . były także migracje handlowe ${ }^{59}$, których celem był zakup i sprzedaż towarów poza swoim krajem. Niemcy, ze względu na geograficzną bliskość i dobrą sieć transportową, były naturalnym kierunkiem tego typu migracji.

\section{Migracje poakcesyjne}

Do czasu wejścia Polski do Unii Europejskiej Niemcy były pierwszym najczęściej wybieranym krajem emigracji Polaków. Do 2006 r. były także krajem europejskim, w którym mieszkało najwięcej polskich obywateli. Po tym roku najpopularniejszym celem migracji Polaków stała się Wielka Brytania.

Tabela 1. Emigracja z Polski na pobyt czasowy w latach 2002-2016 do wybranych krajów europejskich

\begin{tabular}{|l|c|c|c|c|c|c|c|}
\hline \multirow{2}{*}{ Kraj przebywania } & \multicolumn{7}{|c|}{ Liczba emigrantów w tys. } \\
\cline { 2 - 9 } & $\mathbf{2 0 0 2}$ & $\mathbf{2 0 0 4}$ & $\mathbf{2 0 0 6}$ & $\mathbf{2 0 0 8}$ & $\mathbf{2 0 1 0}$ & $\mathbf{2 0 1 2}$ & $\mathbf{2 0 1 6}$ \\
\hline Niemcy & 294 & 385 & 450 & 490 & 430 & 500 & 687 \\
\hline Wielka Brytania & 24 & 150 & 580 & 650 & 580 & 637 & 788 \\
\hline Francja & 21 & 30 & 49 & 56 & 60 & 63 & 64 \\
\hline Włochy & 39 & 59 & 85 & 88 & 92 & 97 & 93 \\
\hline Holandia & 10 & 23 & 55 & 108 & 92 & 97 & 116 \\
\hline
\end{tabular}

Źródło: na podstawie Główny Urząd Statystyczny, Informacja o rozmiarach i kierunkach emigracji z Polski w latach 2004-2009, Warszawa 2010, https://stat.gov.pl/cps/rde/xbcr/gus/lud_infor_o_rozm_i_kierunk_ emigra_z_polski_w_latach_2004_2009.pdf; Cłówny Urząd Statystyczny, Informacja o rozmiarach i kierunkach czasowej emigracji z Polski w latach 2004-2017, Warszawa 2019, file://C:/Users/michal.nowosielski/ Downloads/informacja_o_rozmiarach_i_kierunkach_czasowej_emigracji_z_polski_2004-2017\%20(2).pdf.

Ciekawa jest analiza poakcesyjnych migracji do Niemiec $^{60}$. Po pierwsze, widać wyraźne załamanie rosnącego tuż przed akcesją trendu. O ile jeszcze w 2003 r. liczba polskich obywateli zamieszkujących RFN wynosiła nieco ponad 360 tys., to już w 2004 r. spadła ona poniżej 300 tys. Po drugie, widać wyraźny wzrost dynamiki polskich migracji do Niemiec po 2011 r. Oba te fakty wynikają

57 Zob. np. R. Jończy, Migracje zarobkowe ludności autochtonicznej z województwa opolskiego: studium ekonomicznych determinant $i$ konsekwencji, Wydawnictwo Uniwersytetu Opolskiego, Opole 2003.

58 P. Kaczmarczyk, Polski Berlin? - Uwagi na temat najnowszych migracji Polaków do stolicy Niemiec [w:] Ludzie na huśtawce, red. E. Jaźwińska, M. Okólski, Scholar, Warszawa 2001.

59 K. Pujer, Poakcesyjne migracje zarobkowe Polaków [w:] Ekonomiczno-społeczne aspekty migracji. Wybrane problemy, red. T. Homoncik, K. Pujer, I. Wolańska, Exante, Wrocław 2017.

${ }^{60}$ Więcej na ten temat zob. np. K. Schöll-Mazurek, Między polityką integracyjna a polityka polonijną. Sytuacja najnowszych polskich migrantów w Niemczech $w$ wybranych obszarach po 2011 roku, Księgarnia Akademicka, Kraków 2016. 


\section{Wykres 2. Liczba migrantów z polskim obywatelstwem w Niemczech w latach 2003- 2018}

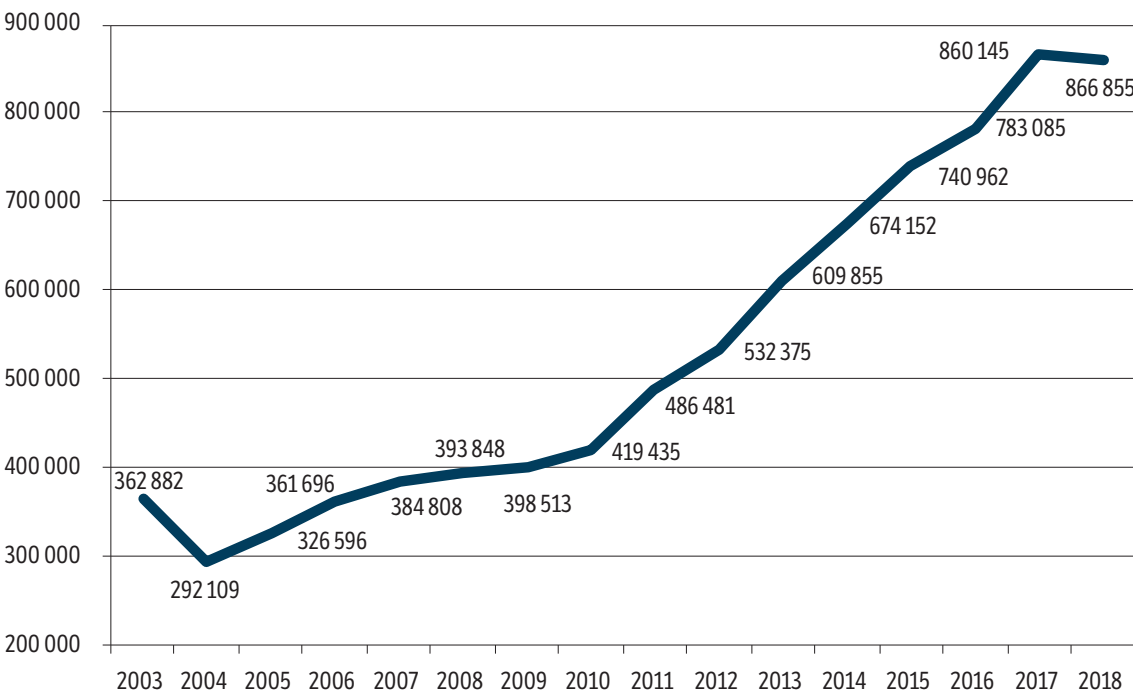

Źródło: Destatis, Bevölkerung und Erwerbstätigkeit Ausländische Bevölkerung sowie Einbürgerungen 2003, Statistisches Bundesamt, Wiesbaden 2005, https://www.destatis.de/GPStatistik/servlets/MCRFileNodeServlet/DEHeft_derivate_00003911/2010200037004.pdf; Destatis, Bevölkerung und Erwerbstätigkeit Ausländische Bevölkerung Ergebnisse des Ausländerzentralregisters 2006, Statistisches Bundesamt, Wiesbaden 2007, https://www.destatis.de/GPStatistik/servlets/MCRFileNodeServlet/DEHeft_derivate_00003968/2010200067004.pdf; Destatis, Bevölkerung und Erwerbstätigkeit Ausländische Bevölkerung Ergebnisse des Ausländerzentralregisters 2010, Statistisches Bundesamt, Wiesbaden 2011, https://www. destatis.de/GPStatistik/servlets/MCRFileNodeServlet/DEHeft_derivate_00003972/2010200107004.pdf; Destatis, Bevölkerung und Erwerbstätigkeit Ausländische Bevölkerung Ergebnisse des Ausländerzentralregisters 2018, Statistisches Bundesamt, Wiesbaden 2019, https://www.destatis.de/DE/Themen/Gesellschaft-Umwelt/Bevoelkerung/Migration-Integration/Publikationen/Downloads-Migration/auslaend-bevoelkerung-2010200187004.pdf?_blob=publicationFile, Destatis, Ausländische Bevölkerung nach ausgewählten Staatsangehörigkeiten, https://www.destatis.de/DE/Themen/Gesellschaft-Umwelt/Bevoelkerung/Migration-Integration/Tabellen/auslaendische-bevoelkerung-staatsangehoerigkeit-jahre.html.

z tego, że RFN nie otworzyło swojego rynku pracy dla migrantów z nowych państw UE bezpośrednio po 2004 r., ale dopiero w 2011 r. Zamknięcie niemieckiego rynku pracy i otwarcie innych możliwości migracyjnych spowodowały odpływ potencjalnych polskich pracowników do innych krajów.

Część polskich migrantów wykorzystywała inne, alternatywne możliwości zatrudnienia w RFN. Po pierwsze, w przypadku niektórych - istotnych z punktu widzenia niemieckiej gospodarki - zawodów zniesiono ograniczenia, ułatwiając tym samym legalne podjęcie pracy w Niemczech. Dotyczyło to takich zawodów jak np. inżynierowie, elektronicy, specjaliści w zakresie budowy maszyn czy 
informatycy. Po drugie, choć zamknięty był rynek pracy, to otwarty pozostał rynek usług. Część Polaków omijała więc niemieckie ograniczenia zatrudnienia przez rejestrację jednoosobowych przedsiębiorst $w^{61}$. Jednak dopiero otwarcie niemieckiego rynku pracy zmieniło sytuację i zdynamizowało napływ polskich migrantów.

Wejście Polski do Unii Europejskiej miało także negatywny wpływ na napływ polskich pracowników sezonowych do Niemiec. O ile jeszcze w 2004 r. ich liczba wynosiła nieco poniżej 300 tys., o tyle już w 2008 r. spadła do mniej niż 200 tys., by w kolejnych latach niemal zupełnie zniknąćć

Mimo tego ze względu na bliskość Polski i bardzo dobrze rozwinięte sieci migracyjne migracje tymczasowe, a szczególnie wahadłowe, pozostają ciągle ważnym elementem polsko-niemieckiego krajobrazu migracyjnego. Dodatkowo wraz z akcesją Polski do UE pojawily się nowe formy migracji tymczasowych i wahadłowych związanych np. z procedurami delegowania pracowników czy też swobodą świadczenia usług.

\section{Charakterystyka społeczno-demograficzna polskiej zbiorowości w Niemczech}

Bliższych danych na temat charakterystyki społeczno-demograficznej polskiej zbiorowości w RFN dostarczają wyniki niemieckiego badania Mikrocenzus, w którym analizuje się informacje o osobach $\mathrm{z}$ tzw. podłożem migracyjnym ${ }^{63}$. Szacuje się, że w 2018 r. w Niemczech mieszkało 2,253 mln Polaków bądź osób, które mają związki migracyjne z Polską, z czego 1,668 mln osób to migranci w pierwszym pokoleniu. W kategorii tej mieści się 232 tys. Polaków naturalizowanych w RFN oraz 860 tys. obywateli Polski ${ }^{64}$. Trudna do oszacowania jest liczba przesiedleńców. Analizując dane Mikrozensus, należy brać pod uwagę, że

${ }^{61}$ Zob. E. Marek, Praca Polaków w Niemczech, op. cit., s. 247; A. Sakson, Problemy migracji zarobkowej w Polsce [w:] Transformacja w Polsce i w Niemczech Wschodnich. Próba bilansu, red. A. Sakson, Instytut Zachodni, Poznań 2009, s. 150.

62 A. Kozak, Polnische Arbeitsmigration nach Deutschland. Eine politikwissenschaftliche Analyse, Masterarbeit zur Erlangung des akademischen Grades „Master of Arts (M.A.)” / „Master of Science (M.Sc.)”, Philosophische Fakultät der Rheinischen Friedrich-WilhelmsUniversität Bonn, Bonn 2019.

${ }^{63}$ Stosowane w niemieckiej statystyce publicznej Personen mit Migrationshintergrund można tłumaczyć na język polski jako osoby o imigracyjnych korzeniach, migracyjnym pochodzeniu, migracyjnym tle lub podłożu i które albo mają własne doświadczenia migracyjne albo są potomkami migrantów.

${ }^{64}$ Destatis, Bevölkerung und Erwerbstätigkeit. Bevölkerung mit Migrationshintergrund Ergebnisse des Mikrozensus 2018, Statistisches Bundesamt, Wiesbaden 2019, https://www. destatis.de/DE/Themen/Gesellschaft-Umwelt/Bevoelkerung/Migration-Integration/Publikationen/Downloads-Migration/migrationshintergrund-2010220187004.pdf?_blob=publicationFile. 
niemieccy badacze wskazują, że liczba osób z polskim pochodzeniem migracyjnym jest najprawdopodobniej zaniżona ${ }^{65}$.

Osoby pochodzące z Polski są drugą, po Turkach, pod względem liczebności zbiorowością imigrancką w RFN. Stanowią oni niemal 11\% wszystkich osób o pochodzeniu migracyjnym w Niemczech (wykres 2).

Tabela 2. Liczebność największych zbiorowości imigranckich w Niemczech w 2018 r.

\begin{tabular}{|l|c|c|c|c|}
\hline Kraj pochodzenia & $\begin{array}{c}\text { Osoby } \\
\text { z pochodzeniem } \\
\text { migracyjnym } \\
\text { (w tys.) }\end{array}$ & $\begin{array}{c}\text { W tym osoby } \\
\text { z własnym } \\
\text { doświadczeniem } \\
\text { migracyjnym } \\
\text { (w tys.) }\end{array}$ & $\begin{array}{c}\text { W tym obywatele } \\
\text { kraju pochodzenia } \\
\text { (w tys.) }\end{array}$ & $\begin{array}{c}\text { Procent obywateli } \\
\text { kraju pochodzenia } \\
\text { w liczbie osób } \\
\text { z pochodzeniem } \\
\text { migracyjnym }\end{array}$ \\
\hline Turcja & 2769 & 1319 & 1476 & 53,3 \\
\hline Polska & 2253 & 1668 & 860 & 38,2 \\
\hline Federacja Rosyjska & 1366 & 1076 & 254 & 18,6 \\
\hline Kazachstan & 1252 & 946 & 46 & 3,7 \\
\hline Rumunia & 965 & 779 & 696 & 72,1 \\
\hline Włochy & 868 & 508 & 644 & 74,2 \\
\hline Syria & 813 & 711 & 746 & 91,8 \\
\hline Grecja & 467 & 298 & 363 & 77,7 \\
\hline Kosowo & 463 & 271 & 218 & 47,1 \\
\hline Bośnia i Hercegowina & 415 & 289 & 100 & 24,1 \\
\hline Austria & 343 & 209 & 187 & 54,5 \\
\hline Serbia & 316 & 207 & 231 & 73,1 \\
\hline
\end{tabular}

Źródło: Destatis, Bevölkerung und Erwerbstätigkeit. Bevölkerung mit Migrationshintergrund - Ergebnisse des Mikrozensus 2018, Statistisches Bundesamt, Wiesbaden 2019, https://www.destatis.de/DE/Themen/Gesellschaft-Umwelt/Bevoelkerung/Migration-Integration/Publikationen/Downloads-Migration/migrationshintergrund-2010220187004.pdf?_blob=publicationFile.

Udział polskich obywateli w zbiorowości osób z polskim tłem migracyjnym wynosi nieco ponad $38 \%$. Pokazuje on specyfikę czy wręcz pewną hybrydowość polskiej zbiorowości w Niemczech na tle innych grup migracyjnych. Z jednej bowiem strony mamy do czynienia ze zbiorowościami w dużej mierze opartymi na migracji przesiedleńców (np. migracja z Kazachstanu, Federacji Rosyjskiej), gdzie odsetek ten jest znacznie niższy. Z drugiej strony mamy też zbiorowości, gdzie tzw. obcokrajowcy (Ausländer) stanowią większość (np. osoby migrujące z Rumunii, Grecji czy ostatnio z Syrii). Migranci z Polski wydają się plasować gdzieś pośrodku tych dwóch zjawisk - $\mathrm{z}$ jednej strony przesiedleńcy stanowią spory odsetek polskiej zbiorowości, z drugiej jednak duża jest też liczba posiadających polskie obywatelstwo.

65 D. Halm et al., Polish and Turkish organizations in Germany [w:] Cross Border Migrant Organizations in Comparative Perspective, eds. L. Pries, Z. Sezgin, Plaggrave, Basingstoke 2012, s. 38. 
Zbiorowość polska w Niemczech jest silnie zróżnicowana wewnętrznie. $\mathrm{Na}$ podstawie niemieckich statystyk publicznych można starać się wskazać kilka jej najważniejszych społeczno-demograficznych cech.

\section{Wiek}

W kategorii osób z polskim pochodzeniem migracyjnych średnia wieku wynosi obecnie 41,4 lat ${ }^{66}$, zaś średnia wieku migrantów z polskim obywatelstwem jest niższa i wynosi 37,8 lat ${ }^{67}$. Faktem, który rzuca się w oczy podczas analizy wieku Polaków mieszkających w Niemczech, są różnice w rozkładach poszczególnych

\section{Wykres 3. Struktura wiekowa osób z polskim pochodzeniem migracyjnym oraz migran- tów z polskim obywatelstwem}

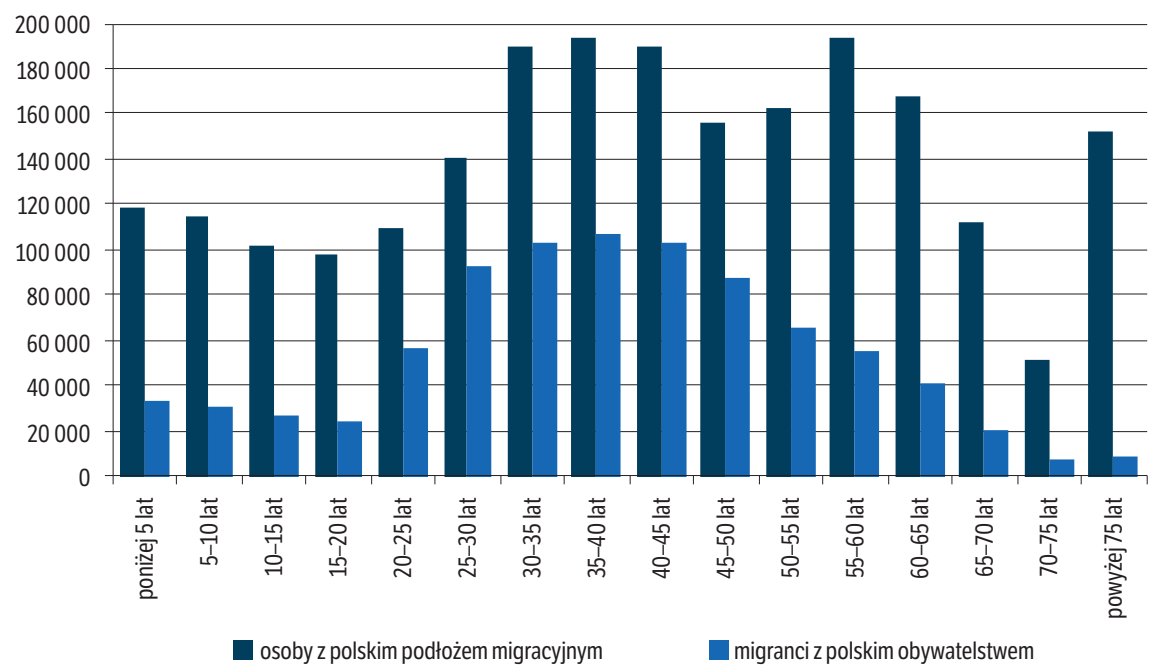

Źródło: Destatis, Bevölkerung und Erwerbstätigkeit. Bevölkerung mit Migrationshintergrund - Ergebnisse des Mikrozensus 2018, Statistisches Bundesamt, Wiesbaden 2019, https://www.destatis.de/DE/Themen/Gesellschaft-Umwelt/Bevoelkerung/Migration-Integration/Publikationen/Downloads-Migration/migrationshintergrund-2010220187004.pdf?_blob=publicationFile; Destatis, Bevölkerung und Erwerbstätigkeit. Ausländische Bevölkerung Ergebnisse des Ausländerzentralregisters 2018, Statistisches Bundesamt, Wiesbaden 2019, https://www.destatis.de/DE/Themen/Gesellschaft-Umwelt/Bevoelkerung/Migration-Integration/Publikationen/Downloads-Migration/auslaend-bevoelkerung-2010200187004.pdf?_blob=publicationFile.

${ }^{66}$ Destatis, Bevölkerung und Erwerbstätigkeit. Bevölkerung mit Migrationshintergrund Ergebnisse des Mikrozensus 2018, Statistisches Bundesamt, Wiesbaden 2019, https://www. destatis.de/DE/Themen/Gesellschaft-Umwelt/Bevoelkerung/Migration-Integration/Publikationen/Downloads-Migration/migrationshintergrund-2010220187004.pdf?_blob=publicationFile.

67 Ibidem. 


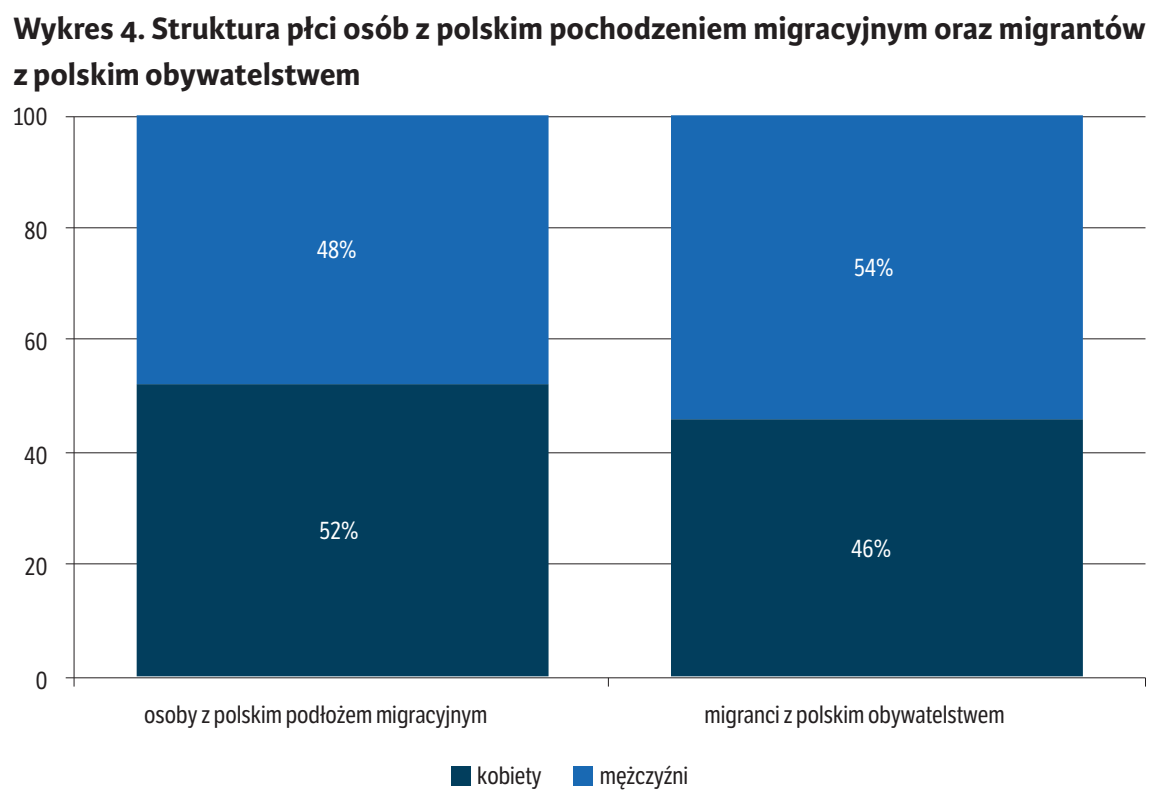

Źródło: Destatis, Bevölkerung und Erwerbstätigkeit. Bevölkerung mit Migrationshintergrund - Ergebnisse des Mikrozensus 2018, Statistisches Bundesamt, Wiesbaden 2019, https://www.destatis.de/DE/Themen/Gesellschaft-Umwelt/Bevoelkerung/Migration-Integration/Publikationen/Downloads-Migration/migrationshintergrund-2010220187004.pdf? blob=publicationFile; Destatis, Bevölkerung und Erwerbstätigkeit Ausländische Bevölkerung Ergebnisse des Ausländerzentralregisters 2018, Statistisches Bundesamt, Wiesbaden 2019, https://www.destatis.de/DE/Themen/Gesellschaft-Umwelt/Bevoelkerung/Migration-Integration/Publikationen/Downloads-Migration/auslaend-bevoelkerung-2010200187004.pdf?_blob=publicationFile.

kategorii wiekowych między obiema grupami. W przypadku polskich obywateli mieszkających na terenie Niemiec widać wyraźnie, że dominują osoby w wieku produkcyjnym. Wskazuje to na ekonomiczny charakter migracji. W przypadku osób z polskim pochodzeniem migracyjnym zwraca z kolei uwagę to, że różnice między kategoriami osób w wieku produkcyjnym i innymi - w mniejszym stopniu przedprodukcyjnym, a w większym poprodukcyjnym - są mniej widoczne. W szczególnie jaskrawy sposób widać to w kategorii osób w wieku powyżej 75 lat. Jest to pewnego rodzaju wskaźnikiem procesów starzenia się zbiorowości Polaków w Niemczech (wykres 3).

\section{Płeć}

Kolejną istotną cechą jest płeć. Tu również obserwujemy ciekawe dysproporcje między obiema analizowanymi kategoriami. W przypadku osób z polskim pochodzeniem migracyjnym daje się zauważyć niewielką przewagę kobiet $(52 \%$ w stosunku do 48\%). Inaczej jest w przypadku migrantów z polskim obywatel- 
stwem, gdzie większa jest liczba mężczyzn niż kobiet (54\% do 46\%). Prawdopodobnie wynika to z migracji zawodowej do branż związanych np. budownictwem (wykres 4).

\section{Czas pobytu}

Inną ważną cechą jest czas pobytu w Niemczech. W 2018 r. średni czas pobytu w RFN w kategorii migrantów z polskim obywatelstwem wyniósł 9,6 lat. Jeśli chodzi o osoby z polskim pochodzeniem migracyjnym oraz własnym doświadczeniem migracyjnym średnia ta jest znacznie wyższa i wynosi 24 lata (wykres 5).

\section{Wykres 5. Deklarowany czas pobytu w Niemczech wśród migrantów z polskim obywa- telstwem w 2018 r.}

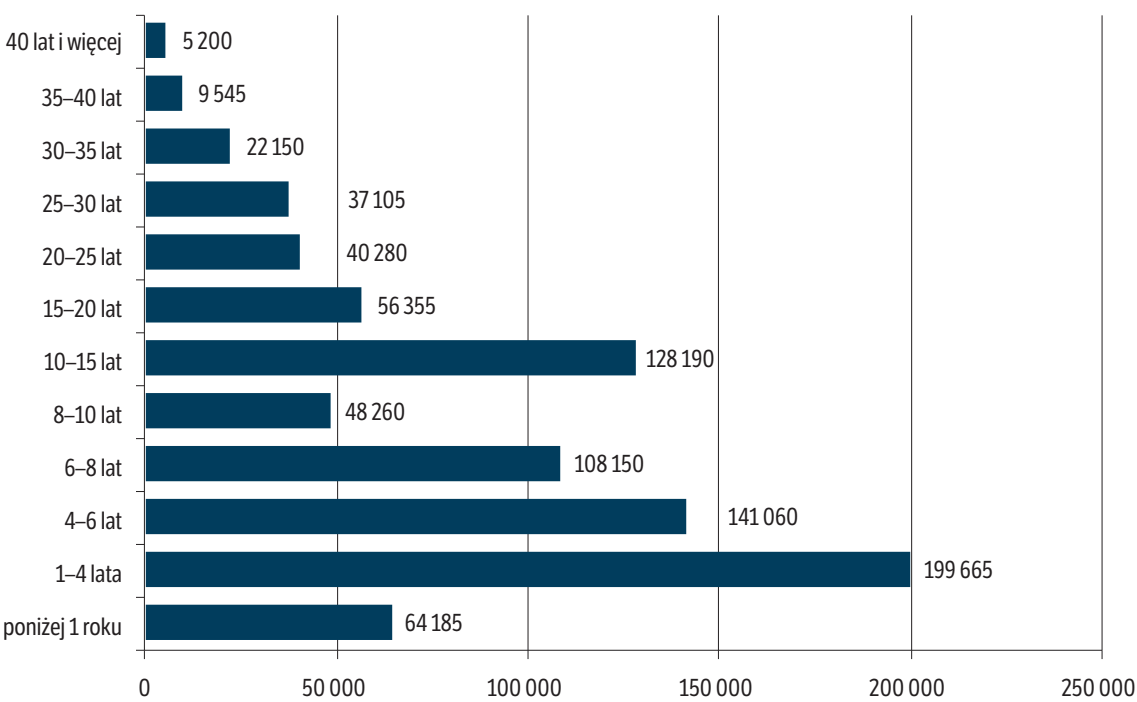

Źródło: Destatis, Bevölkerung und Erwerbstätigkeit Ausländische Bevölkerung Ergebnisse des Ausländerzentralregisters 2018, Statistisches Bundesamt, Wiesbaden 2019, https://www.destatis.de/DE/Themen/Gesellschaft-Umwelt/Bevoelkerung/Migration-Integration/Publikationen/Downloads-Migration/auslaend-bevoelkerung-2010200187004.pdf?_blob=publicationFile.

Dla zbiorowości migrantów z polskim obywatelstwem dostępne są szczegółowe dane pozwalające zobrazować czas pobytu. Wynika z nich, że stosunkowo najliczniejszą kategorią (niemal 200 tys. z 860 tys.) są osoby, które mieszkają w Niemczech od roku do 4 lat. Razem z migrantami, którzy mieszkają na terenie RFN od 4 do 6 lat oraz od 6 do 8, stanowią oni ponad połowę wszystkich Polaków w Niemczech. Potwierdza to tezę, że otwarcie niemieckiego rynku pracy w 2011 r. zdynamizowało procesy migracyjne z Polski do Niemiec. Można też mówić o tym, że w zbiorowości tej zachodzą procesy osadnicze. 
Zwraca także uwagę dość duża liczba osób, które wyemigrowały do Niemiec 10-15 lat temu, czyli mniej więcej w czasie akcesji Polski do UE - są to prawdopodobnie osoby, które skorzystały z nowych możliwości swobody świadczenia usług.

\section{Miejsce zamieszkania}

Kolejną ważną podstawą wewnętrznego zróżnicowania polskiej zbiorowości w RFN jest fakt jej geograficznego rozproszenia. Największa liczba migrantów z Polski mieszka w Nadrenii Północnej-Westfalii (786 tys. osób z polskim pochodzeniem migracyjnym, w tym ok. 220 tys. migrantów z polskim obywatelstwem), Dolnej Saksonii (odpowiednio 255 tys. i ok. 97 tys.), 151 tys.), Badenii-Wirtembergii (240 tys. i ok. 86 tys.) oraz Bawarii (239 tys. i ok. 116 tys.). Takie rozłożenie polskich migrantów wydaje się być uwarunkowane kilkoma czynnikami. Po pierwsze, tradycją polskich migracji do Niemiec, po drugie, wielkością krajów związkowych, po trzecie zaś, ich sytuacją gospodarczą (tabela 3).

Tabela 3. Liczba osób z polskim pochodzeniem migracyjnym i migrantów z polskim obywatelstwem w 2018 r. ze względu na kraj związkowy zamieszkania i płeć

\begin{tabular}{|c|c|c|c|c|c|c|}
\hline \multirow[t]{2}{*}{ Kraj związkowy } & \multicolumn{3}{|c|}{$\begin{array}{l}\text { Osoby z polskim pochodzeniem } \\
\text { migracyjnym }\end{array}$} & \multicolumn{3}{|c|}{ Migranci z polskim obywatelstwem } \\
\hline & Razem & Mężczyźni & Kobiety & Razem & Mężczyźni & Kobiety \\
\hline Nadrenia Północna-Westfalia & 786000 & 375000 & 411000 & 220890 & 117825 & 103060 \\
\hline Dolna Saksonia & 255000 & 125000 & 130000 & 97145 & 53740 & 43405 \\
\hline Badenia-Wirtembergia & 240000 & 119000 & 121000 & 85910 & 46360 & 39555 \\
\hline Bawaria & 239000 & 116000 & 123000 & 115925 & 65765 & 50160 \\
\hline Hesja & 185000 & 93000 & 93000 & 81780 & 43320 & 38460 \\
\hline Berlin & 131000 & 59000 & 72000 & 71475 & 35660 & 35820 \\
\hline Nadrenia-Palatynat & 103000 & 49000 & 55000 & 44375 & 23935 & 20440 \\
\hline Hamburg & 73000 & 36000 & 37000 & 24545 & 12435 & 12110 \\
\hline Szlezwik-Holsztyn & 62000 & 33000 & 29000 & 27630 & 14865 & 12765 \\
\hline Brandenburgia & 39000 & 16000 & 23000 & 20640 & 11545 & 9095 \\
\hline Saksonia & 31000 & 16000 & 15000 & 17785 & 10510 & 7270 \\
\hline Brema & 31000 & 17000 & 14000 & 10685 & 5565 & 5120 \\
\hline $\begin{array}{l}\text { Meklemburgia-Pomorze } \\
\text { Przednie }\end{array}$ & 23000 & 10000 & 12000 & 13105 & 7630 & 5480 \\
\hline Saksonia-Anhalt & 20000 & 10000 & 10000 & 10810 & 6975 & 3840 \\
\hline Turyngia & 17000 & 7000 & 9000 & 11560 & 6940 & 4620 \\
\hline Kraj Saary & 17000 & 8000 & 9000 & 5885 & 2925 & 2960 \\
\hline Razem & 2253000 & 1089000 & 1164000 & 860145 & 465995 & 394160 \\
\hline
\end{tabular}

Źródło: Destatis, Bevölkerung und Erwerbstätigkeit. Bevölkerung mit Migrationshintergrund - Ergebnisse des Mikrozensus 2018, Statistisches Bundesamt, Wiesbaden 2019, https://www.destatis.de/DE/Themen/Gesellschaft-Umwelt/Bevoelkerung/Migration-Integration/Publikationen/Downloads-Migration/migrationshintergrund-2010220187004.pdf? _blob=publicationFile; Destatis, Bevölkerung und Erwerbstätigkeit Ausländische Bevölkerung Ergebnisse des Ausländerzentralregisters 2018, Statistisches Bundesamt, Wiesbaden 2019, https://www.destatis.de/DE/Themen/Gesellschaft-Umwelt/Bevoelkerung/Migration-Integration/Publikationen/Downloads-Migration/auslaend-bevoelkerung-2010200187004.pdf?_blob=publicationFile. 
Warto także zwrócić uwagę na trzy kraje związkowe, które są wydzielonymi miastami, a w których również mieszka wielu migrantów z Polski. Są to: Berlin (131 tys. i ok. 71 tys.), Hamburg (73 tys. i ok. 25 tys.) i Brema (31 tys. i ok. 11 tys.).

\section{Miejsce w strukturze społecznej}

Trudno wskazać jednoznaczne miary mogące mówić o miejscu polskiej zbiorowości w niemieckim społeczeństwie. Warto jednak zwrócić uwagę na pewne „twarde” wskaźniki, takie jak wykształcenie, aktywność zawodowa czy też poziom dochodów. Aby uzyskać możliwie pełny obraz, dane dla osób z polskim pochodzeniem migracyjnym będą prezentowane $\mathrm{w}$ porównaniu z całością zbiorowości imigranckiej w RFN oraz z osobami bez pochodzenia migracyjnego.

Pierwszym analizowanym wskaźnikiem jest wykształcenie. Wyniki wskazują na dość niejednoznaczną sytuację. Z jednej bowiem strony osoby pochodzące z Polski charakteryzują się strukturą wykształcenia podobną do zbiorowości osób bez tła migracyjnego - z dominacją osób o wykształceniu średnim oraz relatywnie niską liczbą osób bez wykształcenia. W tym sensie polska zbiorowość odbiega od średniej dla wszystkich osób z pochodzeniem migracyjnym. Z drugiej jednak strony zwraca uwagę stosunkowo niski odsetek osób o wyższym wykształceniu (13\%), który jest nieco niższy nie tylko w porównaniu z niemigrantami $(16,1 \%)$, ale także ze średnią dla zbiorowości osób z tłem migracyjnym (13,8\%); (wykres 6).

\section{Wykres 6. Struktura wykształcenia dla poszczególnych kategorii w 2018 r.}

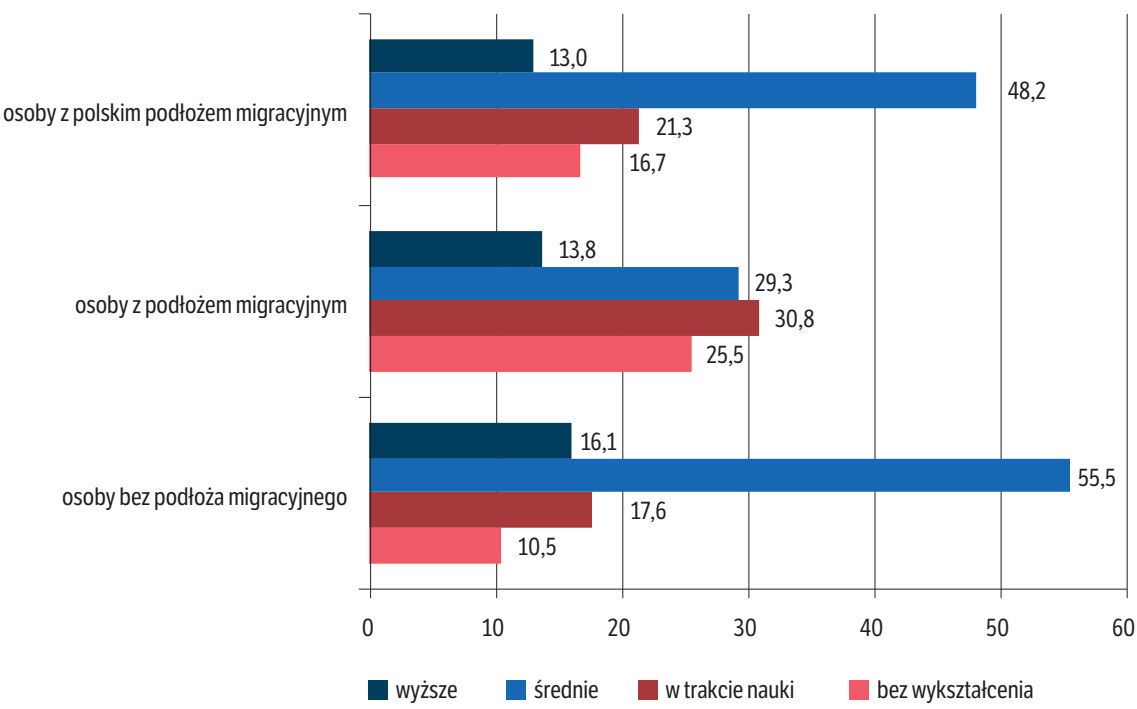

Źródło: Destatis, Bevölkerung und Erwerbstätigkeit. Bevölkerung mit Migrationshintergrund - Ergebnisse des Mikrozensus 2018, Statistisches Bundesamt, Wiesbaden 2019, https://www.destatis.de/DE/Themen/Gesellschaft-Umwelt/Bevoelkerung/Migration-Integration/Publikationen/Downloads-Migration/migrationshintergrund-2010220187004.pdf?_blob=publicationFile. 
Struktura wykształcenia wydaje się znajdować swoje odbicie w strukturze zatrudnienia. Niemieckie statystyki publiczne pokazują wyraźnie, że migranci z Polski są zbiorowością, w której jest relatywnie największy odsetek osób aktywnych zawodowo - 58,3\% w porównaniu z 53,9\% dla osób bez pochodzenia migracyjnego i 51\% dla całej zbiorowości imigranckiej w RFN (tabela 4).

Tabela 4. Struktura zatrudnienia dla poszczególnych kategorii w 2018 r.

(w \%)

\begin{tabular}{|c|c|c|c|c|c|c|c|c|}
\hline \multirow[b]{3}{*}{ Kategoria } & \multirow{3}{*}{ 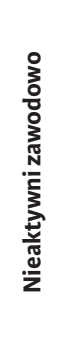 } & \multicolumn{7}{|c|}{ Aktywni zawodowo } \\
\hline & & \multirow[b]{2}{*}{ 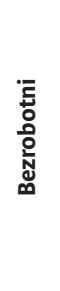 } & \multicolumn{6}{|c|}{ Zatrudnieni } \\
\hline & & & 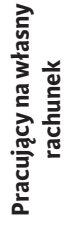 & 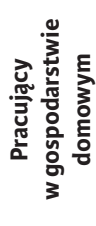 & 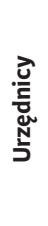 & 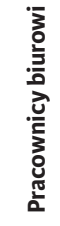 & 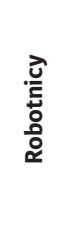 & 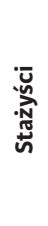 \\
\hline $\begin{array}{l}\text { Osoby bez pochodzenia } \\
\text { migracyjnego }\end{array}$ & 46,1 & 1,4 & 5,2 & 0,2 & 3,1 & 35,0 & 7,3 & 1,7 \\
\hline $\begin{array}{l}\text { Osoby z pochodzeniem } \\
\text { migracyjnym }\end{array}$ & 49,0 & 3,0 & 4,1 & 0,1 & 0,7 & 28,8 & 12,2 & 2,2 \\
\hline $\begin{array}{l}\text { Osoby z polskim } \\
\text { pochodzeniem } \\
\text { migracyjnym }\end{array}$ & 41,7 & 2,0 & 4,9 & 0,0 & 1,0 & 33,2 & 15,7 & 1,4 \\
\hline
\end{tabular}

Źródło: jak pod wykresem 6.

Przy większości kategorii osób aktywnych zawodowo migranci z Polski plasują się między niemigrantami i całą zbiorowością imigrancką w RFN, co wskazuje na dużą aktywność zawodową i radzenie sobie na niemieckim rynku pracy. Zwraca uwagę duży odsetek osób zatrudnionych na stanowiskach robotniczych - aż 15,7\% osób z polskim pochodzeniem migracyjnym zajmuje takie stanowiska - to ponad 2 razy więcej niż w przypadku niemigrantów oraz o ponad 5 pkt proc. więcej niż w całej zbiorowości migracyjnej.

Duża aktywność zawodowa migrantów z Polski znajduje swoje potwierdzenie także w analizie struktury głównych źródeł utrzymania (wykres 7). Okazuje się, że większość osób z polskim pochodzeniem migracyjnym deklaruje, iż praca zawodowa jest ich głównym źródłem dochodu $(51,6 \%)$ - jest to odsetek najwyższy ze wszystkich trzech analizowanych grup. Warto zwrócić uwagę, że migranci z Polski nie korzystają często ze wsparcia socjalnego oferowanego przez niemiecki welfare-state - zarówno w postaci zasiłku dla bezrobotnych (4,4\% w porównaniu z 7,9\% dla całości zbiorowości imigrantów), jak i zasiłków socjalnych ( $2 \%$ w porównaniu z 4,8\% dla całości zbiorowości imigrantów). Świadczy to o tym, że część z niemieckich obaw dotyczących nadmiernego obciążenia systemu opieki społecznej przez migrantów z Polski była oparta na nieprawdziwych przesłankach. 


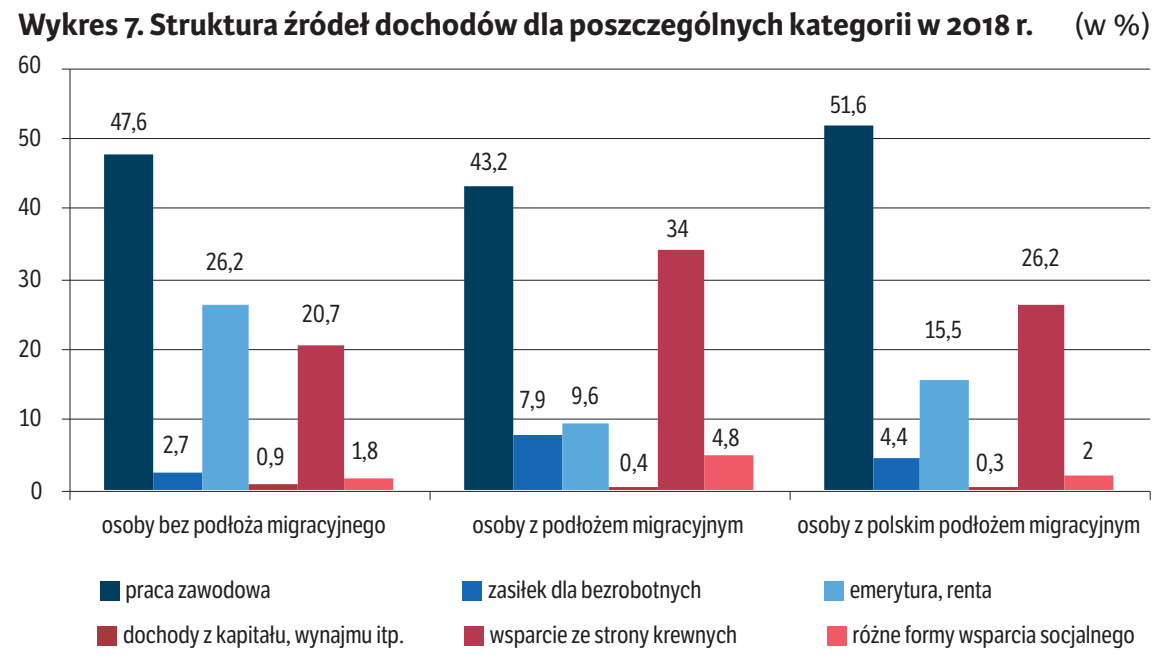

Źródło: jak pod wykresem 6.

Wykres 8. Średnia dochodów dla poszczególnych kategorii w 2018 r.

(w euro)

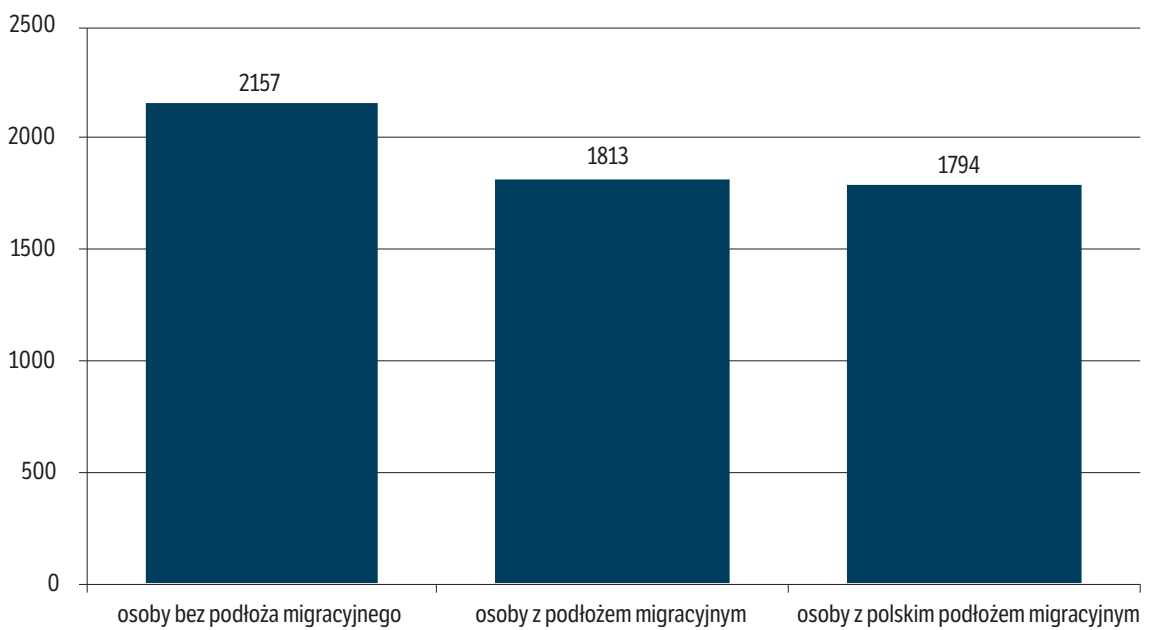

Źródło: jak pod wykresem 6.

Jednak duża aktywność zawodowa niekoniecznie musi przekładać się na dobrą sytuację materialną. Analiza średnich dochodów dla poszczególnych kategorii pokazuje, że średni dochód netto na głowę jest dla zbiorowości polskich migrantów w porównaniu $\mathrm{z}$ dwoma pozostałymi podgrupami najniższy i wynosi zaledwie 1794 euro, podczas gdy średnia dla wszystkich osób o pochodzeniu migracyjnym wynosi 1813 euro, zaś dla niemigrantów aż 2157 euro (wykres 8). 


\section{Podsumowanie}

W czasie ostatnich dwustu lat $\mathrm{z}$ ziem polskich na terytorium Niemiec przeniosło się ponad $8 \mathrm{mln}$ osób ${ }^{68}$. Choć część z tej liczby wróciła do Polski bądź wyemigrowała dalej, to jednak większość związała swoje losy w Niemcami na stałe. Można więc powiedzieć, że procesy migracji z Polski do Niemiec mają charakter długotrwały i są znaczące ilościowo. Silnie bowiem wpływają na strukturę społeczną zarówno społeczeństwa pochodzenia, jak i pobytu. Cechą istotnie wpływającą na kształt współczesnej polskiej diaspory w RFN jest falowość migracji. Migracje te bowiem odbywały się w kilku zasadniczych falach - różniących się od siebie istotnie ze względu na kontekst społeczno-polityczny, motywy migracji, warunki, w jakich następowała migracja, oraz sytuację formalnoprawną. Wśród licznych etapów warto wymienić te najważniejsze - migracje drugiej połowy XIX wieku, które stały się zalążkiem polskiej społeczności w Niemczech, migracje czasu II wojny światowej, które doprowadziły do stworzenia silnej społeczności dipisów, migracje przesiedleńców, którzy - szczególnie wyjeżdżający w latach 80. XX wieku - często zachowywali bliskie związki z kulturą polską czy wręcz z polską tożsamością, migracje solidarnościowe lat 80 ., które trwale odcisnęły swój ślad na wizerunku polskiego migranta w Niemczech, czy w końcu najnowsze migracje przed- i poakcesyjne silnie zmieniające charakter polskiej zbiorowości.

Falowość procesu migracji z Polski do Niemiec powoduje, że Polacy w Niemczech są zbiorowością heterogeniczną. Efekty falowości widać przy analizie długości czasu pobytu, który wskazuje na wyraźną koncentrację w konkretnych okresach. Pogłębiona analiza wskazuje, że poszczególne fale migracyjne nie tylko różnią się od siebie, ale także utrzymują ze sobą ograniczony kontakt i mają tendencję do tworzenia własnych instytucji czy organizacji ${ }^{69}$. Trudno, mówiąc o Polakach w Niemczech, nazywać ich grupą czy społecznością w sensie socjologicznym - dlatego raczej wskazane wydaje się użycie pojęcia „zbiorowość", które podkreśla raczej słabe społeczne więzi między migrantami z Polski. Teza ta znajduje swoje potwierdzenie między innymi w analizie aktywności stowarzyszeniowej. Mimo istnienia dość dużej sieci polskich organizacji, należy stwierdzić, że jest ona raczej rozproszona, słabo wewnętrznie zorganizowana oraz skonfliktowana. Organizacje borykają się z licznymi problemami, takimi jak niedostatki funduszy czy też słabe zaangażowanie społeczne (jedynie ok. 7\% populacji migrantów z Polski angażuje się w działania organizacji ${ }^{70}$.

Heterogeniczność poszczególnych fal migracji jest dodatkowo wzmocniona innymi cechami demograficznymi. Analiza danych statystycznych pozwala na

${ }^{68}$ M. Nowosielski, Polacy $w$ Niemczech, op. cit., s. 3.

69 Zob. M. Nowosielski, Polskie organizacje w Niemczech. Stan i uwarunkowania, Instytut Zachodni, Poznań 2016.

${ }^{70}$ Ibidem. 
ważną obserwację dotyczącą dość dużego rozproszenia terytorialnego polskich migrantów w Niemczech. Największa zbiorowość migrantów z Polski mieszka w Nadrenii Północnej-Westfalii, która była tradycyjnym celem Polaków migrujących do Niemiec w różnych etapach migracji. Są tam dobrze rozwinięte tzw. sieci migracyjne, ułatwiające wychodźcom adaptację w nowym miejscu zamieszkania. Jednak można mówić o tym, że brak jest wyraźnych polskich skupisk. Jest to tym bardziej widoczne, że Polacy mieszkający w RFN nie tworzą własnych „gett”, dzielnic czy ulic.

Drugą ciekawą cechą jest „niewidoczność” bądź „niewidzialność polskiej zbiorowości. Z jednej strony migranci z Polski są drugą - po Turkach - co do wielkości mniejszością imigrancką, z drugiej jednak są oni słabo widoczni zarówno w niemieckiej „ethnospace”, jak i niemieckim dyskursie publicznym. Jedną z potencjalnych przyczyn takiego stanu rzeczy jest ich stosunkowo dobra integracja ze społeczeństwem niemieckim i brak widocznych problemów, jakie ta zbiorowość mogłaby sprawiać w procesie integracji. Można nawet powiedzieć, że ostatnio Polacy stawiani są za swego rodzaju wzór integracji. Daje się zaobserwować ciekawą zmianę nastawienia niemieckiego społeczeństwa do migrantów z Polski. O ile jeszcze w latach 90. XX wieku przybysze z Europy Środkowej, $\mathrm{w}$ tym także z Polski, postrzegani byli negatywnie, szczególnie w porównaniu z generalnie bardziej pozytywnie postrzeganymi imigrantami z krajów Europy Północnej i Południowej ${ }^{71}$, to jednak od czasu przystąpienia Polski i innych państw Europy Środkowej i Wschodniej do UE, stosunek Niemców wyraźnie się poprawił. Migracja z krajów Unii - a dominują w niej osoby z Polski - jest postrzegana daleko bardziej pozytywnie niż emigracja z innych krajów ${ }^{72}$. Zmiana tego wizerunku częściowo jest związana ze zmianami charakteru polskich migracji - szczególnie ograniczeniem migracji handlowych i nielegalnych.

Pewne potwierdzenie tezy o słabej widoczności polskich migrantów dostarczają wyniki niektórych analizowanych statystyk. Jeśli przyjrzymy się danym dotyczącym np. wykształcenia czy zatrudnienia, okaże się, że migranci z Polski zajmują pozycję pośrednią między całą kategorią osób o pochodzeniu migracyjnym a niemigrantami. Są jednak od tej reguły odstępstwa. Migranci z Polski częściej niż wszyscy migranci i niemigranci mają wykształcenie średnie, częściej pracują jako robotnicy i są częściej aktywni zawodowo. Są także grupą, dla której najczęściej praca zawodowa jest ich głównym źródłem dochodu. Co ciekawe, mimo danych wskazujących na dużą aktywność na rynku pracy, ich średnie dochody są najniższe ze wszystkich porównywanych zbiorowości. Można więc mówić o tym, że Polacy odróżniają się od tych dwóch kategorii. Warto jednak

71 R.J. Simon, J.P. Lynch, A Comparative Assessment of Public Opinion toward Immigrants and Immigration Policies, „International Migration Review” 1999, No 2.

72 German Marshall Fund of the United States, Transatlantic Trends: Mobility, Migration and integration, Key Findings from 2014 and Selected Highlights from Transatlantic Trends and Transatlantic Trends: Immigration 2008-13, 2014, http://www.gmfus.org/file/3482/download. 
podkreślić, że zwykle różnice te nie mają zdecydowanego charakteru i nie mogą stanowić przesłanki do mówienia o jakichś wyraźnie specyficznych cechach polskiej zbiorowości. Tezę o dobrej integracji polskich migrantów potwierdzają także najnowsze wyniki dotyczące ich uczestnictwa w kulturze, które wskazują, że choć są oni przywiązani do polskiej kultury i języka, to jednocześnie wielu $\mathrm{z}$ nich postrzega Niemcy jako miejsce, które mogą nazywać domem ${ }^{73}$.

\section{Bibliografia}

Cichocki P., Lewandowska A., Nowosielski M., Dynamika niemieckiej opinii publicznej. Wizerunek Polski i Polaków w Niemczech, „IZ Policy Papers” 2013, nr 8.

Cimała A., Polacy w Berlinie w XIX i XX wieku [w:] Polacy w Niemczech, red. M. Lis, Instytut Śląski, Opole 1996.

Fiałkowska K., Remote fatherhood and visiting husbands: seasonal migration and men's position within familie, „Comparative Migration Studies” 2019, No 2.

Galos A., Stan liczebny emigracji polskich w XIX wieku [w:] Liczba i rozmieszczenie Polaków w świecie, cz. 1, Uniwersytet Wrocławski, Wrocław 1981.

Grabe W., Górnośląscy „przesiedleńcy” w Niemczech [w:] Być Polakiem w Niemczech, red. A Wolff-Powęska, E. Schulz, Instytut Zachodni, Poznań 2000.

Halm D. et an., Polish and Turkish organizations in Germany [w:] Cross Border Migrant Organizations in Comparative Perspective, eds. L. Pries, Z. Sezgin, Plaggrave, Basingstoke 2012.

Heffner K., Polacy w Niemczech - rozmieszczenie i liczebność [w:] Polacy w Niemczech, red. M. Lis, Instytut Śląski, Opole 1996.

Janowska H., Emigracja $z$ Polski w latach 1918-1939 [w:] Emigracja z ziem polskich w czasach nowożytnych i najnowszych (XVIII-XX w.), red. A. Pilch, PWN, Warszawa 1984.

Janusz G., Polonia w Niemczech [w:] Polonia w Niemczech. Historia i współczesność, Elipsa, Warszawa 2001.

Janusz G., Polonia w Republice Federalnej Niemiec, UMCS, Lublin 1990.

Jeran A., Nowak W., Nowosielski M., Migranci z Polski w Niemczech - aspekty kulturowe. Raport z badań, Ośrodek Badań nad Migracjami UW, Warszawa 2019.

Jończy R., Migracje zarobkowe ludności autochtonicznej z województwa opolskiego: studium ekonomicznych determinant $i$ konsekwencji, Wydawnictwo Uniwersytetu Opolskiego, Opole 2003.

Kaczmarczyk P., Polski Berlin? - Uwagi na temat najnowszych migracji Polaków do stolicy Niemiec [w:] Ludzie na huśtawce: migracje między peryferiami Polski i Zachodu, red. E. Jaźwińska, M. Okólski, Scholar, Warszawa 2001.

Kępińska E., Migracje sezonowe z Polski do Niemiec, Wydawnictwa Uniwersytetu Warszawskiego, Warszawa 2008.

${ }_{73}$ A. Jeran, W. Nowak, M. Nowosielski, Migranci z Polski w Niemczech-aspekty kulturowe. Raport z badań, Ośrodek Badań nad Migracjami UW, Warszawa 2019. 
Kołodziej E., Wychodźstwo zarobkowe z Polski 1918-1939. Studia nad polityką emigracyjną II Rzeczypospolitej, Książka i Wiedza, Warszawa 1982.

Korczyńska J., Sezonowe wyjazdy Polaków do Niemiec, Scholar, Warszawa 2003.

Kozak A., Polnische Arbeitsmigration nach Deutschland. Eine politikwissenschaftliche Analyse, Masterarbeit zur Erlangung des akademischen Grades „Master of Arts (M.A.)” / „Master of Science (M.Sc.)”, Philosophische Fakultät der Rheinischen Friedrich-Wilhelms-Universität Bonn, Bonn 2019.

Kozłowski J., Geneza i ewolucja zbiorowości wychodźstwa polskiego w Europie [w:] Polonia w Europie, red. B. Szydłowska-Cegłowa, Zakład Badań Narodowościowych PAN, Poznań 1992.

Krajewski M., Historia gospodarcza Polski do 1989 roku, Wyższa Szkoła Humanistyczno-Ekonomiczna, Włocławek 2000.

Landau Z., Polityka ludnościowa Niemiec hitlerowskich za ziemiach polskich $w$ latach II wojny światowej, „Wiadomości Historyczne. Czasopismo dla Nauczycieli” 1964, t. $7, \mathrm{nr} 4$.

Lesiuk W., Polska emigracja wewnątrzniemiecka i do Niemiec okresu industrializacji [w:] Polacy w Niemczech, red. M. Lis, Instytut Śląski, Opole 1996.

Lesiuk W., Trzcielinska-Polus A., Wokół definicji przedmiotu badań [w:] Być Polakiem w Niemczech, red. A. Wolff-Powęska, E. Schulz, Instytut Zachodni, Poznań 2000.

Lis M., Polska mniejszość narodowa w Niemczech po odzyskaniu niepodległości przez Polskę [w:] Polacy w Niemczech, red. M. Lis, Instytut Śląski, Opole 1996.

Liman S., Polacy w Niemczech po II wojnie światowej [w:] Polonia w Europie, red. B. Szydłowska-Cegłowa, Zakład Badań Narodowościowych PAN, Poznań 1992.

Loew P., Wir Unsichtbaren. Geschichte der Polen in Deutschland, CH Beck Verlag, München 2014.

Łuczak C., Przemieszczenia ludności z Polski podczas drugiej wojny światowej [w:] Emigracja $z$ ziem polskich $w$ czasach nowożytnych i najnowszych (XVIII-XX w.), red. A. Pilch, PWN, Warszawa 1984.

Marek E., Praca Polaków w Niemczech. Póttora wieku emigracji zarobkowej, IPISS, Warszawa 2008.

Miera F., Transnationalisierung sozialer Raeume? Migration aus Polen nach Berlin in den 80er und 90er Jahren [w:] Die Migration von Polen nach Deutschland. Zu Geschichte und Gegenwart eines europäischen Migrationssystems, ed. Ch. Pallaske, Nomos Verlagsgesellschaft, Baden-Baden 2001.

Nowosielski M., Polacy $w$ Niemczech. Stan i perspektywy badań, „Przegląd Zachodni” 2012, nr 3.

Nowosielski M., Polskie organizacje w Niemczech. Stan i uwarunkowania, Instytut Zachodni, Poznań 2016.

Nowosielski M., Stefańska R., Repatriacja [w:] 25 wykładów o migracjach, red. M. Lesińska, M. Okólski, Scholar, Warszawa 2018.

Panayi P., Ethnic Minorities in Nineteenth and Twentieth Century Germany. Jews, Gypsies, Poles, Turks and Others, Longman, Harlow 2000. 
Pilch A., Emigracja z ziem zaboru austriackiego (od połowy XIX w. do 1918 r.) [w:] Emigracja $z$ ziem polskich $w$ czasach nowożytnych i najnowszych (XVIII-XX w.), red. A. Pilch, PWN, Warszawa 1984.

Plich A., Ogólne prawidłowości emigracji z ziem polskich. Próba typologii i syntezy [w:] Stan i potrzeby badań nad zbiorowościami polonijnymi, red. H. Kubiak, A. Pilch, Zakład Narodowy im. Ossolińskich, Wrocław 1976.

Pujer K., Poakcesyjne migracje zarobkowe Polaków [w:] Ekonomiczno-społeczne aspekty migracji. Wybrane problemy, red. T. Homoncik, K. Pujer, I. Wolańska, Exante, Wrocław 2017.

Ruchniewicz K., Die polnische politische Emigration nach Deutschland in den Jahren 1945 bis 1980 [w:] Die Migration von Polen nach Deutschland. Zu Geschichte und Gegenwart eines europäischen Migrationssystems, ed. Ch. Pallaske, Nomos Verlagsgesellschaft, Baden-Baden 2001.

Sakson A., Problemy migracji zarobkowej w Polsce [w:] Transformacja w Polsce i w Niemczech Wschodnich. Próba bilansu, red. A. Sakson, Instytut Zachodni, Poznań 2009.

Schmidtke O., Die „unsichtbare” polnische Community in Deutschland: Die strategische Entdramatisierung von kollektiver Identität [w:] Die Einhegung des Anderen. Türkische, polnische und russlanddeutsche Einwanderer in Deutschland, eds. K. Eder, V. Rauer, O. Schmidtke, VS Verlag, 2004.

Schmidt J., Nowe tożsamości w czasach transformacji europejskich. Imigranci z Polski w Niemczech, Wydawnictwo News - Witold Nowak, Poznań 2009.

Schöll-Mazurek K., Między polityką integracyjną a polityka polonijną. Sytuacja najnowszych polskich migrantów w Niemczech w wybranych obszarach po 2011 roku, Księgarnia Akademicka, Kraków 2016.

Simon R.J., Lynch J.P., A Comparative Assessment of Public Opinion toward Immigrants and Immigration Policies, „International Migration Review” 1999, nr 2.

Slany K., Emigracja z Polski w latach osiemdziesiątych do głównych krajów imigracji zamorskiej i kontynentalnej: aspekty demograficzno-społeczne, „Przegląd Polonijny” 1991, t. 62, nr 4.

Trzcielińska-Polus A., Imigracja z Polski do Niemiec w okresie stanu wojennego i po zmianie ustroju w Polsce [w:] Polacy w Niemczech, red. M. Lis, Instytut Śląski, Opole 1996.

Trzcielińska-Polus A., „Wysiedleńcy” z Polski w Republice Federalnej Niemiec w latach 1980-1990, Instytut Śląski, Opole, 1997.

Wagner M., Fiałkowska K., Piechowska M., Łukowski W., Niemiecki proszek do prania i polnische Wirtschaft. Polscy robotnicy sezonowi w Niemczech - obserwacje etnograficzne, Scholar, Warszawa 2016.

Wolak Ł., Środowisko Zjednoczenia Polskich Uchodźców w RFN. Przyczynek do badań [w:] Z dziejów polskiej emigracji politycznej po 1939 r. Ludzie, struktury, idee, red. P. Pleskot, IPN, Warszawa 2019.

Wrzesiński W., Państwo narodowe i świadomość narodowa [w:] Być Polakiem w Niemczech, red. A. Wolff-Powęska, E. Schulz, Instytut Zachodni, Poznań 2000. 


\section{Źródła internetowe}

Destatis, Bevölkerung und Erwerbstätigkeit Ausländische Bevölkerung sowie Einbürgerungen 2003, Statistisches Bundesamt, Wiesbaden 2005, https://www.destatis.de/GPStatistik/servlets/MCRFileNodeServlet/DEHeft_derivate_00003911/2010200037004. pdf.

Destatis, Ausländische Bevölkerung nach ausgewählten Staatsangehörigkeiten, https:// www.destatis.de/DE/Themen/Gesellschaft-Umwelt/Bevoelkerung/Migration-Integration/Tabellen/auslaendische-bevoelkerung-staatsangehoerigkeit-jahre.html.

Destatis, Bevölkerung und Erwerbstätigkeit Ausländische Bevölkerung Ergebnisse des Ausländerzentralregisters 2006, Statistisches Bundesamt, Wiesbaden 2007, https:// www.destatis.de/GPStatistik/servlets/MCRFileNodeServlet/DEHeft_derivate_00003968/2010200067004.pdf.

Destatis, Bevölkerung und Erwerbstätigkeit Ausländische Bevölkerung Ergebnisse des Ausländerzentralregisters 2010, Statistisches Bundesamt, Wiesbaden 2011, https:// www.destatis.de/GPStatistik/servlets/MCRFileNodeServlet/DEHeft_derivate_00003972/2010200107004.pdf.

Destatis, Bevölkerung und Erwerbstätigkeit Ausländische Bevölkerung Ergebnisse des Ausländerzentralregisters 2018, Statistisches Bundesamt, Wiesbaden 2019, https://www. destatis.de/DE/Themen/Gesellschaft-Umwelt/Bevoelkerung/Migration-Integration/Publikationen/Downloads-Migration/auslaend-bevoelkerung-2010200187004. pdf?_blob=publicationFile.

Destatis, Bevölkerung und Erwerbstätigkeit. Bevölkerung mit Migrationshintergrund - Ergebnisse des Mikrozensus 2018, Statistisches Bundesamt, Wiesbaden 2019, https://www.destatis.de/DE/Themen/Gesellschaft-Umwelt/Bevoelkerung/ Migration-Integration/Publikationen/Downloads-Migration/migrationshintergrund-2010220187004.pdf?_blob=publicationFile.

German Marshall Fund of the United States, Transatlantic Trends: Mobility, Migration and integration, Key Findings from 2014 and Selected Highlights from Transatlantic Trends and Transatlantic Trends: Immigration 2008-13, 2014, http://www.gmfus. org/file/3482/download.

Główny Urząd Statystyczny, Informacja o rozmiarach i kierunkach emigracji $z$ Polski w latach 2004-2009, Warszawa 2010, https://stat.gov.pl/cps/rde/xbcr/gus/lud_infor_o_rozm_i_kierunk_emigra_z_polski_w_latach_2004_2009.pdf.

Główny Urząd Statystyczny, Informacja o rozmiarach i kierunkach czasowej emigracji z Polski w latach 2004-2017, Warszawa 2019, https://stat.gov.pl/download/gfx/portalinformacyjny/pl/defaultaktualnosci/5471/2/11/1/informacja_o_rozmiarach_i_kierunkach_czasowej_emigracji_z_polski_2004-2017.pdf.

„Welt am Sonntag”, http://www.infratest-dimap.de/umfragen-analysen/bundesweit/umfragen/aktuell/gutes-verhaeltnis-zwischen-deutschen-und-polen. 